\title{
PENGARUH PENGELUARAN PEMERINTAH TERHADAP PASAR MATA UANG LUAR NEGERI DI INDONESIA: SUATU APLIKASI MODEL CCC-GARCH
}

\author{
La Ode Saidi \\ Fakultas Matematika dan Ilmu Pengetahuan Alam, Universitas Halu Oleo, Kendari \\ E-mail: $\underline{\text { saidilaode45@gmail.com }}$ \\ Rosnawintang \\ Fakultas Ekonomi dan Bisnis, Universitas Halu Oleo, Kendari \\ E-mail: nanarosnawintang@yahoo.co.id \\ Pasrun Adam \\ Fakultas Matematika dan Ilmu Pengetahuan Alam, Universitas Halu Oleo, Kendari \\ E-mail: adampasrun@gmail.com \\ Wali Aya Rumbia \\ Fakultas Ekonomi dan Bisnis, Universitas Halu Oleo, Kendari \\ E-mail: ayarumbia@gmail.com
}

\begin{abstract}
ABSTRAK
Penelitian ini bertujuan untuk menguji pengaruh pengeluaran pemerintah terhadap pasar mata uang luar negeri di Indonesia menggunakan model CCC-GARCH untuk menganalisi data runtun waktu kuartalan yang merentang dari 1985 hingga 2018. Hasil uji memberikan evidens empirik dimana kenaikan pengeluaran pemerintah menyebabkan kurs domestik tedepresiasi (atau kurs mata uang luar negeri terapresiasi). Hal ini menunjukkan bahwa pengeluaran pemerintah memiliki pengaruh terhadap pasar mata uang luar negeri.
\end{abstract}

Kata Kunci: Kurs, model CCC-GARCH, pengeluaran pemerintah,

\section{ABSTRACT}

This study aims to examine the effect of government spending on the foreign currency market in Indonesia using the CCC-GARCH model to analyze quarterly time series data spanning from 1985 to 2019. The test results provide empirical evidence that an increase in government spending causes the domestic exchange rate to depreciate (or the foreign exchange rate to depreciate). This shows that government spending has an influence on foreign currency market.

Keywords: CCC-GARCH model, exchange rate, government spending.

\section{PENDAHULUAN}

Mata uang luar negeri memainkan peran penting dalam perdagangan dunia. Mata uang ini berfungsi sebagai alat transaksi baik dalam aktivitas impor barang maupun ekspor barang. Dalam pasar keuangan khususnya pasar mata uang luar negeri, mata uang ini (termasuk mata uang domestik) menjadi intrumen pasar mata uang luar negeri. Kurs merupakan harga mata uang, dan kurs ini telah menarik perhatian besar para pengambil kebijakan dan akademisi. Banyak peneliti di dunia telah memberi perhatian untuk meneliti tentang faktor-faktor yang mempengaruhi kurs. Diantara faktorfaktor itu adalah: pertumbuhan ekonomi dan suku bunga (Dropsy, 1996), pertumbuhan penawaran uang (Levin, 1997), pengeluaran pemerintah (Balvers dan Bergstrand, 2002), inflasi (Dilmaghani dan Tehranchian, 2015; Purnomo, 2017), harga beras (Adam et al., 2018), ekspor dan impor (Rahim et al., 2020 ), harga minyak (Castro, dan Jiménez-Rodríguez, 2020; Suliman dan Abid, 2020; Saidi et al., 2020), produksi minyak (Ji et al., 2020), dan obligasi (Rosnawintang et al., 2021),

Penelitian ini fokus pada pengeluaran pemerintah sebagai variabel indipenden. Sama halnya dengan mata uang luar negeri, pengeluaran pemerintah juga memiliki peran penting dalam perekonomian suatu negara. Peran ini terutama untuk menstabilkan perekonomian melalui kebijakan 
Jurnal Progres Ekonomi Pembangunan (JPEP)

Volume 6, Nomor 2. Tahun 2021

Page: $69-77$

http://ojs.uho.ac.id/index.php/JPEP

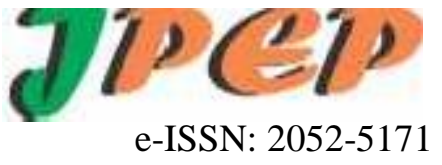

fiskal (Ravn et al., 2012). Para ahli ekonomi telah meneliti pengaruh pengeluaran pemerintah terhadap kurs baik secara teori maupun secara empirik. Secara teori, penelitian dilakukan via pengembangan model matematika, misalnya Balvers dan Bergstrand (2002) dan Chen dan Liu (2017). Menurut kalibrasi model matematika yang mereka bangun, ekspansi pengeluaran pemerintah menyebabkan kurs mata uang domestik terapresiasi (kurs mata uang luar negeri terdepresiasi). Walaupun demikian, dalam penelitian empirik, hasil uji pengaruh memberikan hasil penelitian yang berbeda. Misalnya, Kim dan Roubini (2008) dan Enders et al. (2011) menemukan bahwa kenaikan pengeluaran pemerintah menyebabkan kurs domestik terapresiasi. Hal ini kontradiksi dengan hasil penelitian Bestma et al. (2008) dimana ia menemukan bahwa ekspansi pengeluaran pemerintah menyebabkan kurs mata uang domestik terdepresiasi. Perbedaan penelitian-penelitian tersebut menimbulkan suatu pertanyaan "Bagaimanakah pengaruh pengeluaran pemerintah terhadap kurs mata uang luar negeri di Indonesia?. Apakah kurs mata luar negeri terdepresiasi atau terapresiasi?"

Sejauh yang kami ketahui, penelitian-penelitian terdahulu mengenai pengaruh pengeluaran pemerintah terhadap kurs lebih banyak dilaksanakan di kelompok negara-negara tertentu dalam bentuk panel, dan masih kurang dilaksanakan di negara-negara tunggal. Di Indonesia misalnya, penelitian tentang pengaruh pengeluaran pemerintah terhadap kurs mata uang luar negeri dilakukan oleh Prakoso (2018). Ia menggunakan model VAR untuk menganalis data kurtalan yang merentang dari 2010q1 hingga 2016q1. Hasil uji menunjukkan bahwa kenaikan pengeluaran pemerintah menyebabkan kurs domestik terdepresiasi.

Tujuan penelitian ini adalah menguji pengeluaran pemerintah terhadap pasar mata uang luar negeri yang merupakan replikasi terhadap penelitian Prakoso (2018) namun ditinjau sisi periode penggunaan data dan model analisis berbeda. Kami menggunakan data tahunan dengan periode waktu yang lebih lama yakni dari 1985 hingga 2018. Karena variabel indipenden penelitian ini adalah pasar mata uang luar negeri maka kami menggunakan kurs dua jenis mata uang luar negeri yakni kurs mata uang Jepang (YEN) dan kurs mata uang Amerika Serikat (USD). Kedua kurs ini diukur dalam satuan mata uang rupiah (IDR). Selanjutnya, untuk menganalis data, kami menggunakan model CCCGARCH. Novita dan Nchrowi (2015) dan Adam et al. (2021) mengemukakan bahwa perbedaanperbedaan ini dapat memberikan hasil penelitian yang berbeda.

Paper ini disusun dengan struktur sebagai berikut. Bagian kedua adalah kajian pustaka yang mereview hasil-hasil penelitian empirik terdahulu yang relevan. Bagian ketiga adalah metode penelitian yang membahas langkah-langkah pengujian pengaruh pengeluaran pemerintah terhadap pasar mata uang luar negeri berkenaan dengan penggunaan model CCC-GARCH. Bagian kempat adalah hasil penelitian dan pembahasan yang menguraikan hasil analisis data dan pembahasan tentang temuan, dan bagian kelima adalah kesimpulan dan saran.

\section{KAJIAN PUSTAKA}

Pada bagian ini, kami mereview beberapa hasil penelitian empirik yang relevan. Review ini kami kelompokkan ke dalam dua kelompok penelitian, yakni kelompok penelitian yang dilaksanakan di negara-negar tertentu (tunggal) dan kelompok penelitian yang dilakukan di kelompok negara dalam bentuk panel.

Pada kelompok penelitian di negara-negara tunggal dilakukan oleh antara lain, Cebi dan Culha (2014) menginvestigasi pengaruh kejutan pengeluaran pemerintah terhadap kurs Lira di Turki. Mereka menggunakan model SVAR untuk menganalis data bulanan dalam periode Januari 2002 hingga April 2014. Hasil analisis mereka menunjukkan bahwa kejutan positif pengeluaran pemerintah menyebabkan kurs domestik LIRA terapresiasi. Hasil penelitian ini serupa dengan hasil penelitian Chen dan Liu (2018) dimana, mereka juga menemukan bahwa kenaikan pengeluaran pemerintah menyebakan kurs mata uang domestik China terapresiasi. Bajo-Rubio dan Berke (2018) menguji pengaruh pengeluaran pemerintah (yang terdiri dari pengeluaran konsumsumsi dan pengeluaran investasi) terhadap kurs di Spanyol menggunakan data tahunan dari 1999 hingga 2016. Dengan menggunakan model regresi dinamik dalam menganalisis data, mereka menemukan bahwa penurunan pengeluaran konsumsi menyebabkan kurs mata uang domestik terdepresiasi. Sedangkan, penurunan 
Jurnal Progres Ekonomi Pembangunan (JPEP)

Volume 6, Nomor 2. Tahun 2021

Page: $69-77$

http://ojs.uho.ac.id/index.php/JPEP

pengeluaran investasi menyebabkan kurs mata uang domestik terapresiasi. Ferara et al. (2020) menguji pengaruh pengeluaran pemerintah terhadap kurs mata uang Amerika Serikat menggunakan data kuartalan yang merentang dalam periode 1964q1-2015q4. Hasil uji menggunakan model SVAR, mereka menemukan bahwa kenaikan pengeluaran pemerintah menyebabkan kurs terapresiasi. Nuru (2020) menguji kejutan pengeluaran pemerintah terhadap kurs di Afrika Selatan menggunakan data kuartalan dalam periode 1970q1-2019q2. Hasil analisis menggunakan model VAR, ia menemukan bahwa kejutan positif pengeluaran pemerintah menyebabkan kurs terapresiasi. Gidey dan Nuru (2021) menguji efek pengeluaran pemerintah terhadap kurs di Etiopia. Untuk maksud ini, mereka membagi pengeluaran pemerintah menjadi dua komponen, yakni pengeluaran konsumsi dan pengeluaran investasi. Untuk menguji efek kedua komponen ini, mereka menggunakan model VAR dan data kuartalan dalam periode 2001q1-2016q1. Hasil uji mereka memberikan ksesimpulan bahwa kenaikan pengeluaran konsumsi menyebabkan kurs terapresiasi, sedangkan pengaruh kenaikan pengeluaran investasi menyebabkan kurs terdepresiasi.

Akhirnya pada kelompok penelitian di kelompok negara-negara dilakukan oleh antara lain, Monacelli dan Perotti (2010) mengekstimasi pengaruh pengeluaran pemerintah terhadap kurs di Amerika Serikat dan 3 negara-negara yang termasuk dalam kelompok OECD (Australia, Kanada Inggeris) menggunakan data kuartalan dalam periode dari Januari 1980 hingga April 2006. Hasil estimasi mereka menggunakan model panel VAR menunjukkan bahwa kenaikan pengeluaran pemerintah menyebabkan kurs terdepresiasi. Caporale et al. (2011) menganalisis efek kejutan kebijakan fiskal dalam bentuk pengeluaran pemerintah terhadap kurs di negara-negara Amerika Latin (Argentina, Meksiko, Bolivia, Brazil, Chili dan Peru) menggunakan data kuartalan yang merentang dalam periode 1980-2006. Hasil penelitian mereka menunjukkan bahwa pengeluaran pemerintah mempengaruhi kurs. Sama halnya dengan penelitian Monacelli dan Perotti (2010), Ravn et al. (2012) mendokumentasikan pengaruh pengeluaran pemerintah terhadap kurs di tiga negara-negra tersebut ditambah dengan negara Amerika Serikat (yang selanjutnya di sebut kelompok negara-negara industri) selama periode kejadian Bretton Wood. Hasil pengujian mereka menggunakan model panel SVAR, mereka menemukan bahwa kenaikan pengeluaran pemerintah mempengaruhi kurs dimana kurs mata uang negara domestik terdepresiasi. Dengan menggunakan model panel data, Miyamoto et al. (2019) meneliti pengaruh pengeluaran pemerintah terhadap kurs di 125 negara. Mereka membagi grup negara-negara ini menjadi dua sub negara-negara, yakni sub negara-negara berkembang, dan sub negara-negara sedang berkembang. Mereka ingin membandingkan apakah pengaruh pengeluaran pemerintah terhadap kurs mata uang domestik berbeda antara di sub negara-negara berkembang (maju) dan di sub negara-negara sedang berkembang. Berdasarkan hasil analisis terhadap data yang merentang dari 1989 hingga 2013, mereka menemukan bahwa kenaikan pengeluaran pemerintah menyebabkan kurs terapresiasi di sub negara-negara berkembang, sedangkan di sub negara-negara sedang berkembang kurs mata uang domestik terdepresiasi. Ibhagui (2019) menguji pengeruh pengeluaran pemerintah terhadap kurs di negara-negara Sub-Sahara Afrika menggunakan data dalam periode 1980-2011. Serupa dengan penelitian Gidey dan Nuru (2021), ia juga membagi pengeluaran pemerintah atas 2 komponen, yakni pengeluaran konsumsi dan pengeluaran investasi. Hasil uji panel data menunjukkan bahwa pengruh kedua komponen pengeluaran pemerintah beragam, dimana di beberapa negara menunjukkan bahwa kedua komponen pengeluaran pemerintah mempengaruhi kurs, sementara pengaruh ini di beberapa nega lainnya tidak ada. Pengaruh pengeluaran konsumsi terhadap kurs mata uang domestik adalah negatif, artinya jika pengeluaran konsumsi naik, maka kurs mata uang domestik terapresiasi. Sementara itu, pengaruh kenaikan pengeluaran investasi menyebabkan kurs mata uang domestik terdepresiasi.

\section{METODE PENELITIAN}

Penelitian ini menggunakan dua variabel penelitian, yakni pengeluaran pemerintah sebagai variabel indipenden dan pasar mata uang luar negeri sebagai variabel dependen. Proksi variabel pasar mata uang luar negeri adalah kurs mata uang Yen Jepang dan kurs mata uang USD Amerika Serikat. Di dalam perdagangan international, kedua mata uang ini termasuk mata uang dunia yang umum 
Jurnal Progres Ekonomi Pembangunan (JPEP)

Volume 6, Nomor 2. Tahun 2021

Page: $69-77$

http://ojs.uho.ac.id/index.php/JPEP

digunakan dalam transaksi perdagangan internasional, selain mata uang EURO (Amadeo, 2020). Inilah yang menjadi alasan mengapa kedua mata uang ini di pilih sebagai proksi dari variabel pasar mata uang luar negeri.

Penelitian ini menggunakan data runtun waktu tahunan yang merentang dari 1985 hingga 2018. Satuan ukuran pengeluaran pemerintah adalah IDR, sedangkan satuan ukuran kurs Yen dan USD adalah IDR. Sumber data pengeluaran pemerintah dan kurs adalah Bank St Louist, Amerika Serikat. Untuk keperluan analisis, kami menggunakan logaritma natural dari data kedua runtun waktu tersebut. Kami memberi notasi GOV untuk penegeluaran pemerintah, YEN untuk kurs mata uang Jepang, dan USD untuk kurs mata uang Amerika Serikat.

Untuk menguji pengaruh pengeluaran pemerintah terhadap pasar mata uang luar negeri, kami menggunakan model Contant Conditional Correlation Generalized Autoregressive Conditional Heteroscedasticity (CCC-GARCH). Model ini dikembangkan pertama kali oleh Bollerslev (1990), kemudian dipublikasikan oleh para peneliti di banyak buku teks ekonometrika, antara lain: Francq dan Zakoian (2010) dan Brooks (2014). Model CCC-GARCH dengan panjang lag waktu p dan q, di tulis CCC-GARC $(p, q)$ yang menyatakan hubungan antara pengeluaran pemerintah dan pasa mata uang luar negeri dispesifikasikan dengan sistem persamaan berikut

$$
\begin{aligned}
& U S D_{t}=C_{11}+C_{12} G_{O} O V_{t}+\varepsilon_{1 t} \\
& Y E N_{t}=C_{21}+C_{22} G O V_{t}+\varepsilon_{2 t} \\
& h_{k k, t}=w_{k}+\sum_{i=1}^{q} a_{k, i} \varepsilon_{k,(t-i)}{ }^{2}+\sum_{j=1}^{p} b_{k, j} h_{k k,(t-j)}, k=1,2 \\
& h_{12}=\rho_{12} \sqrt{h_{11, t}} \sqrt{h_{22, t}}
\end{aligned}
$$

Gabungan persamaan (1a) dan (1b) dinamakan persamaan mean, sedangkan gabungan antara (2a) dan (2b) disebut persamaan varians. Selanjunya, $C_{i j}(i, j=1,2), w_{k}(k=1,2), a_{k, i}(k=1,2 ; i=$ $1,2, \ldots, q)$ dan $b_{k, j}(k=1,2 ; j=1,2, \ldots, p)$ adalah parameter-parameter persamaan-persamaan. $\varepsilon_{1 t}$ dan $\varepsilon_{2 t} \quad(t=1985, \ldots, 2018)$ masing merupakan error persamaan (1a) dan (1b). Variabel-variabel $h_{k k, t}(k=1,2)$ dan $h_{12, t}$ merupakan varians dan kovarian eror $\varepsilon_{1 t}$ dan $\varepsilon_{2 t}$, sedangkan $\rho_{12}(-1 \leq$ $\left.\rho_{12} \leq 1\right)$ adalah koefisien korelasi antara $\varepsilon_{1 t}$ dan $\varepsilon_{2 t}$ yang didefinisikan dengan

$$
\rho_{12}=\frac{E\left(\varepsilon_{1 t} \varepsilon_{2 t} \mid \varepsilon_{u}, u<t\right)}{\left\{E\left(\varepsilon_{1 t}{ }^{2} \mid \varepsilon_{u}, u<t\right) E\left(\varepsilon_{2 t}{ }^{2} \mid \varepsilon_{u}, u<t\right)\right\}^{\frac{1}{2}}}
$$

Parameter-parameter $w_{k}(k=1,2), a_{k, i}(k=1,2 ; i=1,2, \ldots, q)$ dan $b_{k, j}(k=1,2 ; j=1,2, \ldots, p)$ memenuhi $w_{k}>0, a_{k, i} \geq 0$ dan $b_{k, j} \geq 0$.

Jika $\left(\eta_{t}\right)$ bariasan variabel yang berdistribusi identik dan indipenden, $R$ matriks korelasi, $w$ vektor kontanta positif berukuran $2 \times 1, A_{i}(i=1,2, \ldots, q)$ dan $B_{j}(j=1,2, \ldots, p)$ adalah matriksmatriks tak negatif yang berukuran $2 \times 2$, maka dalam bentuk multivariat, persamaan varians (2a) dan (2b) dapat dinyatakan dalam bentuk persamaan-persamaan matriks di (3)

$$
\varepsilon_{t}=H_{t}^{\frac{1}{2}} \eta_{t}
$$

$H_{t}=D_{t} R D_{t}$

$\underline{h}_{t}=\underline{w}+\sum_{i=1}^{q} A_{i} \underline{\varepsilon}_{(t-i)}+\sum_{j=1}^{p} B_{j} \underline{h}_{(t-j)}$

dimana $\underline{h}_{t}=\left(\begin{array}{l}h_{11, t} \\ h_{22, t}\end{array}\right), D_{t}=\left(\begin{array}{cc}\sqrt{h_{11, t}} & 0 \\ 0 & \sqrt{h_{22, t}}\end{array}\right)$ dan $\underline{\varepsilon}_{t}=\left(\begin{array}{c}\varepsilon_{1, t}^{2} \\ \varepsilon_{2, t}^{2}\end{array}\right)$. Vektor eror $\varepsilon_{t}$ beristribusi identik, indipenden dan normal multivariat dengan mean vektor nol dan varians vector $\underline{h}_{t}$ (Francq dan Zakoian, 2010; IHS Markit, 2017).

Langkah-langkah pengujian pengaruh pengeluaran pemerintah terhadap pasar mata uang luar negeri adalah sebagai berikut. Pada langkah pertama, kami mengestimasi parameter-parameter persamamaan-persamaan mean (1a) dan (1b) dan persamaan varians (2a) atau (3). Metode estimasi yang digunakan adalah metode quasilikelihood Gausian yakni dengan cara memaksimumkan fungsi likelihood (4)

$$
L_{2}=L_{2}\left(\theta ; \varepsilon_{1}, \varepsilon_{2}\right) \prod_{t=1}^{n} \frac{1}{2 \pi\left|\widetilde{H}_{t}\right|^{\frac{1}{2}}} \exp \left(-\frac{1}{2} \varepsilon_{t}{ }^{\prime} \widetilde{H}_{t}^{-1} \varepsilon_{t}\right)
$$


Jurnal Progres Ekonomi Pembangunan (JPEP)

Volume 6, Nomor 2. Tahun 2021

Page: $69-77$

http://ojs.uho.ac.id/index.php/JPEP

Pada fungsi likelihood di (4), $\theta$ merepresentasikan himpunan parameter-parameter persamaan (1a),

(1b) dan (2a) atau (3). Sementara itu, $\widetilde{H}_{t}$ memenuhi $\widetilde{H}_{t}=\widetilde{D}_{t} R \widetilde{D}_{t}$ dengan $\widetilde{D}_{t}=\left\{\operatorname{diag}\left(\underline{h}_{t}\right)\right\}^{\frac{1}{2}}$. Pada langkah ini, kami juga menghitung koefisien korelasi $\rho_{12}$ di persamaan (2b).

Pada langkah kedua, kami menguji asumsi model, yakni autokorelasi dan normalitas. Untuk menguji autokorelasi eror, kami menggunakan uji Portmanteau multivariat, sedangkan untuk menguji normalitas eror, kami mengguunakan uji Jarque Bera multivariat. Jika asumsi ini terpenuhi, maka hasil estimasi parameter-parameter akan memberikan kesimpulan tentang ada atau tidaknya pengaruh pengeluaran pemerintah terhadap pasar mata uang luar negeri.

\section{HASIL DAN PEMBAHASAN}

\section{Hasil Penelitian}

Untuk menguji pengaruh pengeluaran pemerintah terhadap pasar mata uang luar negeri menggunakan model CCC-GARCH, maka pada langkah pertama, kami memilih pajang lag waktu $\mathrm{p}=\mathrm{q}=1$. Dengan demikian, untuk menguji pengaruh ini, kami mengestimasi parameter-parameter model CCC-GARCH $(1,1)$. Hasil estimasi parameter-parameter model menggunakan metode quasilikelihood, kami rangkum dalam Tabel 1. Cara estimasi adalah dengan memaksimumkan fungsi likelihood di (4) yakni dengan mendeferensialkan secara parsial terhadap tiap parameter model. Cara ini dilakukan dengan menggunakan bantuan program aplikasi Eview10.

\section{Tabel 1}

Hasil Estimasi Model CCC-GARC $(1,1)$

\begin{tabular}{|c|c|c|c|c|}
\hline $\begin{array}{c}\text { Variabel } \\
\text { indipenden dan } \\
\text { konstanta }\end{array}$ & Koefisien & $\begin{array}{c}\text { Standar deviasi } \\
\text { eror }\end{array}$ & $\begin{array}{c}\text { Nilai statistik z } \\
\text { hitung }\end{array}$ & $\begin{array}{l}\text { Probabilitas } \\
\end{array}$ \\
\hline \multicolumn{5}{|c|}{ Panel 1: Persamaan 1a, variabel dependen: USD } \\
\hline$C_{1}$ & 4.9336 & 0.4331 & 11.3909 & 0.0000 \\
\hline GOV & 0.1740 & 0.0159 & 10.9371 & 0.0000 \\
\hline $\begin{array}{l}\text { Koefisien } \\
\text { determinasi }\left(R^{2}\right)\end{array}$ & 0.1512 & & & \\
\hline Nilai Statistik & & & & \\
\hline $\begin{array}{l}\text { Durbin Watson } \\
\text { (DB) }\end{array}$ & 0.4768 & & & \\
\hline \multicolumn{5}{|c|}{ Panel 2: Persamaan 1b, variabel dependen: YEN } \\
\hline$C_{2}$ & -3.2415 & 0.000805 & -4025.775 & 0.0000 \\
\hline GOV & 0.3168 & $6.01 \mathrm{E}-06$ & 52724.90 & 0.0000 \\
\hline $\begin{array}{l}\text { Koefisien } \\
\text { determinasi }\left(R^{2}\right)\end{array}$ & 0.3072 & & & \\
\hline Nilai Statistik & & & & \\
\hline $\begin{array}{l}\text { Durbin Watson } \\
\text { (DB) }\end{array}$ & 0.7218 & & & \\
\hline \multicolumn{5}{|c|}{ Panel 3: Persamaan varians } \\
\hline$w_{1}$ & 0.0024 & 0.0006 & 3.8104 & 0.0001 \\
\hline$\varepsilon_{1,(t-1)^{2}}$ & -0.3092 & 0.0009 & -349.8015 & 0.0000 \\
\hline$h_{11,(t-1)}$ & 1.2332 & 0.0005 & 2448.127 & 0.0000 \\
\hline$w_{2}$ & -0.0003 & 0.0012 & -0.2985 & 0.7653 \\
\hline$\varepsilon_{2,(t-1)^{2}}$ & -0.2015 & 0.2249 & -0.8960 & 0.3703 \\
\hline$h_{22,(t-1)}$ & 1.0744 & 0.3984 & 2.6965 & 0.0070 \\
\hline$\rho_{12}$ & 0.6426 & 0.1933 & 3.3242 & 0.0009 \\
\hline
\end{tabular}

Dengan memperhatikan Tabel 1, nampak bahwa pada Panel 1, koefisien variabel GOV adalah signifikan $1 \%$. Ini menunjukkan bahwa dengan taraf signifikan $1 \%$ tidak ada alasan untuk menolak hipotesis yang menyatakan bahwa pengeluaran pemerintah mempengaruhi kurs mata uang USD Amerika Serikat. Pada Panel 2, koefisien variabel GOV juga signifikan 1\% sehingga kami 
Jurnal Progres Ekonomi Pembangunan (JPEP)

Volume 6, Nomor 2. Tahun 2021

Page: $69-77$

http://ojs.uho.ac.id/index.php/JPEP

menyimpulkan bahwa pengeluaran pemerintah mempengaruhi kurs mata uang YEN Jepang. Pada Panel 3, konstanta $w_{1}$ dan koefisien-koefisien $\varepsilon_{1,(t-1)}{ }^{2}, h_{11,(t-1)}, h_{22,(t-1)}$ adalah signifikan $1 \%$. Demikian pula koefisien korelasi $\rho_{12}$ adalah signifikan $1 \%$. Di sini, kami tidak memberikan interprestasi mengenai nilai-nilai parameter-parameter persamaan varians: $\varepsilon_{1,(t-1)}{ }^{2}, h_{11,(t-1)}$, $\varepsilon_{2,(t-1)}{ }^{2}$ dan $h_{22,(t-1)}$. Bahwa sesuai penjelasan dalam literatur-literatu ekonometrik, nilai parameter-parameter ini belum bisa ditafsirkan maknanya secara fisis (lihat Brooks, 2014).

Pada langkah selanjutnya, adalah kami menguji asumsi eror (residual) model CCC$\operatorname{GARCH}(1,1)$. Pertama, kami menguji asumsi normalitas menggunakan uji Jarque Bera. Hasil estimasi statistik uji ini diberikan di Tabel 2. Nilai probabilitas kedua eror persamaan (1a) dan eror persamaan (1b) adalah lebih besar dari taraf signifikansi 1\%. Artinya, kedua eror ini berdistribusi normal. Sementara itu, berdasarkan uji Jarque Bera multivariat, eror gabungan juga signifikan 1\%. Dengan perkataan lain, eror model CCC-GARCH $(1,1)$ tidak berdistribusi normal.

Tabel 2

Hasil Ettimasi Statistik Uji Jarque Bera

\begin{tabular}{cccc}
\hline Eror & Nilai statistik Jarque Bera & Derajad bebes & Probabilitas \\
\hline Persamaan (1a) & 6.4740 & 2 & 0.0393 \\
Persamaan (1b) & 0.5950 & 2 & 0.7427 \\
Joint persamaan (1a) dan (1b) & 7.0690 & 4 & 0.1323 \\
\hline
\end{tabular}

Selanjutnya, kami menguji asumsi autokorelasi eror model CCC-GARCH $(1,1)$ menggunakan uji Portmonteau. Kami menghitung statistik uji ini mulai dari panjang lag waktu 1 hingga panjang lag waktu 3. Hasil perhitungan nilai statistik uji Portmanteua diberikan di Tabel 3. Pada semua lag waktu, nilai statistik uji Portmonteau signifikan 5\%. Dengan demikian, eror model CCC-GARCH $(1,1)$ tidak memiliki autokorelasi.

Tabel 3

Hasil Estimasi Statistik Uji Portmonteau

\begin{tabular}{ccc}
\hline Panjang lag waktu & Nilai statistik uji Q (Portmonteau) & Probabiltas \\
\hline 1 & 7.976648 & 0.0924 \\
2 & 10.52545 & 0.2301 \\
3 & 11.39431 & 0.4955 \\
\hline
\end{tabular}

Dengan terpenuhinya dua asumsi klasik tentang eror (normalitas dan autokorelasi) maka kesimpulan mengenai hasil uji pengaruh yakni pengeluaran pemerintah mempengaruhi pasar mata uang luar negeri adalah valid. Pengaruh ini adalah sangat kuat, karena kedua koefisien variabel pengeluaran pemerintah di persamaan (1a) dan (1b) signifikan 1\%. Kesimpulan ini didukung pula dengan hasil perbandingan nilai koefisien determinasi $R^{2}$ dan nilai statistik DB dimana $R^{2}<D B$. Perbandingan kedua nilai statistik ini mengindikasikan bahwa hasil estimasi persamaan regresi (1a) dan (1b) bukanlah persamaan-persamaan regresi linear sederhana yang palsu.

\section{Pembahasan}

Temuan penelitian ini adalah kenaikan pengeluaran pemerintah menyebabkan kurs mata uang luar negeri terapresiasi. Temuan ini sejalan dengan temuan-temuan: Bestma et al. (2008), Monacelli dan Perotti (2010), Ravn et al. (2012), Prakoso (2018) serta Bajo-Rubio dan Berke (2018). Temuan ini tidak sejalan dengan temuan-temuan: Cebi dan Culha (2014), Chen dan Liu (2018), Ferara et al., (2020) Nuru (2020), Gidey dan Nuru (2021), Miyamoto et al. (2019), Kim dan Roubini (2008) dan Enders et al. (2011). Perbedaan ini bisa disebabkan oleh karateristik negara-negara dimana penelitian dilakukan, misalnya: sosial ekonomi, budaya dan politik (Ozturk, 2010). Alasan lainnya adalah munculnya antisipasi tentang potensi kenaikan tarif pajak oleh pihak swasta dimana pihak ini beranggapan bahwa jika tariff pajak tidak naik maka konsumsi dan investasi mereka akan lancar (Prakoso, 2018). 
Jurnal Progres Ekonomi Pembangunan (JPEP)

Volume 6, Nomor 2. Tahun 2021

Page: $69-77$

http://ojs.uho.ac.id/index.php/JPEP

Sehubungan dengan temuan ini, maka usulan kebijakan yang perlu dilakukan oleh pemerintah adalah berupa kebijakan penanganan pengeluaran pemerintah yang harus dikendalikan agar sejalan dengan kebijakan moneter Bank Sentral Republik Indonesia yakni mengendalikan inflasi dan menstabilkan mata uang rupiah terhadap mata uang luar negeri. Dalam hal ini kenaikan tariff pajak perlu dikendalikan bahkan tidak dinaikkan

\section{KESIMPULAN}

Pengeluaran pemerintah memainkan peran penting dalam perekonomian suatu negara. Peran ini terutama adalah dalam konteks pelaksanaan kebijakan fiskal untuk menstabilkan variabel-variabel makroekonomi lainnya termasuk kurs mata uang. Penelitian ini bertujuan untuk menguji pengaruh pengeluaran pemerintah terhadap pasar mata uang luar negeri yang di proksi dengan kurs mata uang YEN Jepang dan kurs mata uang USD Amerika Serikat. Kami menggunakan data runtun waktu tahunan yang merentang dari 1985 hingga 2018. Untuk menganalis data, kami menggunakan model CCC-GARCH.

Hasil uji menunjukkan bahwa pengeluaran pemerintah mempengaruhi secara signifikan kedua kurs YEN dan USD. Kenaikan pengeluaran pemerintah menyebabkan kurs mata uang YEN dan USD terapresiasi terhadap kurs mata uang Indonesia (IDR). Hal ini memberi kesimpulan bawa pengeluaran pemerintah mempengaruhi pasar mata uang luar negeri.

Temuan ini dapat memberi masukkan kepada pemerintah berupa kebijakan penanganan pengeluaran pemerintah yang harus dikendalikan agar sejalan dengan kebijakan moneter Bank Sentral Republik Indonesia. Kebijakan moneter yang sedang dicanangkan oleh bank Sentral adalah penetapan suku bunga pada periode waktu yang dapat mengendalikan inflasi dan menstabilkan mata uang rupiah terhadap mata uang luar negeri.

\section{DAFTAR PUSTAKA}

Adam, P., Cahyono, E., Mukhsar., Millia, H., Abapihi, A., Mukhtar, N., \& Lilis, L. O. (2021). Statistical analysis on the effect of exchange rate on stock price in Indonesia: an application of ARDL and IGARCH models. Journal of Physics: Conference Series, 1899(2021)012117, 1-9.

Adam, P., Rosnawintang., Saidi, L. O., Tondi, L., \& Sani, L. O. A. (2018). The causal relationship between crude oil price, exchange rate and rice price. International Journal of Energy Economics and Policy, 8(1), 90-94.

Amadeo, K. (2020). Why the US dollar is the global currency. New York: The Balance. Diakses dari https://www.thebalance.com/world-currency-

3305931\#: :textA\%20global\%20currency\%20is\%20one, the \%20euro\%2C\%20and\%20the\%20yen pada 30 Juni 2021.

Balvers, R. J., \& Bergstrand, J. H. (2002). Government expenditure and equilibrium real exchange rates. Journal of International Money and Finance, 21, 667-692.

Beetsma, R., Giuliodori, M., \& Klaassen, F. (2008). The effects of public spending shocks on trade balances and budget deficits in the European union. Journal of the European Economic Association. 6(2-3), 414-423.

Bollerslev, T. (1990). Modelling the coherence in short-run nominal exchange rates: A multivariate generalized ARCH model. Review of Economics and Statistics, 72, 498-505.

Brooks, C. (2014). Introductory economics for finance, $3^{\text {rd }}$ Ed. New York: Cambrige University Press.

Caporale, G. M., Ciferri, D., \& Girardi, A. (2011). Fiscal shocks and real exchange rate dynamics: Some evidence for Latin America. Journal of International Money and Finance, 30, 709-723.

Castro, C., \& Jime'nez-Rodri'gue, R. (2020). Dynamic interactions between oil price and exchange rate. Plos One, 15(8), 1-20.

Cebi, C., \& Culha, A. A. (2014). The effects of government spending shocks on the real exchange rate and trade balance in Turkey. Applied Economics, 46(26), 3151-3162.

Chen, Y., \& Liu, D. (2018). Government spending shocks and the real exchange rate in China: Evidence from a sign-restricted VAR model. Economic Modelling, 68, 543-554. 
Jurnal Progres Ekonomi Pembangunan (JPEP)

Volume 6, Nomor 2. Tahun 2021

Page: $69-77$

http://ojs.uho.ac.id/index.php/JPEP

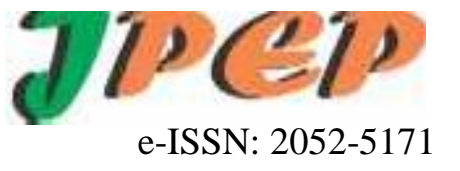

Dilmaghani, A. K., \& Tehrancian, A. M. (2015). The Impact of monetary policies on the exchange rate: A GMM approach. Iranian Econpmic Review, 19(2), 177-191.

Dropsy, V. (1996). Macroeconomic determinants of exchange rates: a frequency-specific analysis. Applied Economics, 28, 55-63.

Enders, Z., Müller, G. J., \& Scholl, A. (2011). How do fiscal and technology shocks affect real exchange rates? New evidence for the United States. Journal International Economic, 83 (1), 53-69.

Ferrara, L., Metelli, L., Natoli, F., \& Siena, D. (2020). Questioning the puzzle: Fiscal policy, exchange rate and inflation. Banque De France Working Paper No. 752, 1-28. Diakses dari https://papers.ssrn.com/sol3/papers.cfm?abstract_id=3526007.

Francq, C., \& Zakoian, J-M. (2010). Garch models structure, statistical inference and financial applications. Chichester: Wiley \& Son Ltd.

Gidey, H. T., \& Nuru, N. Y. (2021). The effects of government spending shocks on real exchange rate in Ethiopia. Journal of Economic and Administrative Sciences, ahead-of-print No. ahead-ofprint. https://doi.org/10.1108/JEAS-07-2020-0137.

IHS-Markit. (2017). Eview 10 user's guide II. Irvin: IHS Global Inc.

Ibhagui, O. (2019). Government spending patterns and the real exchange rate in Sub-Saharan Africa. African Development Review, 31(3), 335-347.

Ji, Q., Shahzad, S. J. H., Bouri, E., \& Suleman, M. T. (2020). Dynamic structural impacts of oil shocks on exchange rates: Lessons to learn. Journal of Economic Structures, 9(20), 1-19.

Kim, S., \& Roubini, N. (2008). Twin deficit or twin divergence? Fiscal policy, current account, and real exchange rate in the U.S. Journal of International Econonomic, 74 (2), 362-383.

Levin, J. H., (1997). Money supply growth and exchange rate dynamics. Journal of Economic Integration, 12(3), 1997; $344-358$.

Miyamoto, W., Nguyen, T. L., \& Sheremirov, V. (2019). The effects of government spending on real rxchange rates: Evidence from military spending panel data. Journal of International Economics, 116, 144-157.

Novita, M., \& Nachrowi, N. D. (2015). Dynamic analysis of stock price index and exchange rate using vector autoregression (VAR) empirical study in JSX, 2001-2004. Researchgatenet.

Nuru, N. Y. (2020). Government spending shocks and external competitiveness: Evidence from South Africa. Journal of International Commerce, Economics and Policy, 11(03), 2050013 (2020). Diakses dari https://www.worldscientific.com/doi/10.1142/S1793993320500131.

Ozturk, I. (2010). A literature survey on energy-growth nexus. Energy Policy, 38(1), 340-349.

Prakoso, I. (2018). The impact of government expenditure on the real exchange rate: An empirical study in Indonesia, Didalam Gani, L., Gitaharie, B., Husodo, Z ., \& Kuncoro, A (eds), Competition and Cooperation in Economics and Business, the Proceedings of the Asia-Pacific Research in Social Sciences and Humanities. London: Taylor \& Francis Group.

Purnomo, A. (2017). The effect of inflation on the currency exchange rate seen in the Islamic Finance. Muqtasid, 8(1), 61-77.

Rahim, M., Millia, H., Adam, P., \& Saidi, L. O. (2020). Causality relation among export, import and exchange rate in Indonesia. International Journal of Scientific \& Technology Research, 9(03), 3096-3102.

Ravn, O., Schmitt-Grohe, S., \& Uribe, M. (2012). Consumption, government spending, and the real exchange rate. Journal of Monetary Economics, 59, 215-234.

Rosnawintang., Syarif, M., Indrijawati, A., Adam, A., \& Saidi, L. O. (2021). The causal relationship between exchange rates and bond yield in Indonesia. Iranian Economic Review, 25(1), 167178. 
Saidi, L. O., Aedy, H., Saranani, F., Rosnawintang., Adam, P., \& Sani, L. O. A. (2020). Crude oil price and exchange rate: An analysis of the asymmetric effect and volatility using the Non Linear Autoregressive Distributed Lag and General Autoregressive Conditional Heterochedasticity in Mean Models. International Journal of Energy Economics and Policy, 10(1), 104-108.

Suliman, T. H. M., \& Abid, M. (2020). The impacts of oil price on exchange rates: Evidence from Saudi Arabia. Energy Exploration and Exploitation, 38(5), 2037-2058. 